\title{
The impact of society perception towards flood disaster incident response plan in Ledok Wetan village, Bojonegoro districts
}

\author{
Rizqi Syafrudin ${ }^{1, *}$ \\ ${ }^{1}$ Postgraduate student at Department of Geography, University Of Indonesia, Depok City, 16424, West Java
}

\begin{abstract}
One of the areas affected by the floods at the end of 2016 was Ledok Wetan village, Bojonegoro district, Bojonegoro regency. The location was very concave or lower than Bengawan Solo River. The purpose of this research is to investigate the influence of public perception about the flood disaster emergency response plan in Ledok Wetan, Bojonegoro district, Bojonegoro regency. This research was conducted in February - April 2017 located in Ledok Wetan Village, Bojonegoro, Bojonegoro District. The research method used was a quantitative method with the survey approach. The population in this research is all head of the family (KK) in Ledok Wetan, Bojonegoro (district), Bojonegoro Regency of East Java Province, which had 46 head of the family (KK). The sample we used just a simple random sampling method. Data analysis technique in this research using quantitative analysis, using the Statistical Product and Solution Program (SPSS) version 16.0. Data analysis technique used was Pearson Product Moment (PPM) technique Based on the results of the study, it can be concluded that there was an influence between the public perception of the flood disaster on the plan of emergency response of flood disaster. The results of analysis Pearson Product Moment obtained value (r) of 0.933 which means having a very strong relationship or influence. Based on the determinant coefficient (R), the figure is $87 \%$. These results obtained information that theoretically the public perception of flood disaster was effected on the flood disaster emergency response plan.
\end{abstract}

\section{Introduction}

Floods are the abundance of normal limits of flow, bodies of water, or accumulation of water in areas not normally submerged (17). In addition, flood is overflowing water from the canal and inundating the surrounding area [1]. In general, the causes of flooding can be categorized into 2 (two) things, namely due to natural causes and because of human actions [2]. Influence of catchment water factors such as size, shape, position, topography, geology and agricultural cultivation determine the occurrence of floods [3]. The degree of vulnerability varies depending on exposure characteristics, such as the level of design, construction materials, demographics, geographical location, and others [4]. The impact of floods will occur on several aspects with several damage levels on aspects of population, government, economy, facilities, infrastructure, and environment [5].

Urban floods typically lead to the destruction or damage of property, thus reproducing or worsening poverty among vulnerable groups in society [6]. They also have negative impacts on health. Strong currents and electrocution can cause injuries or death. Furthermore, floods often pose a high risk of the rapid spread of communicable diseases, such as diarrhea, influenza and skin infections [7] or induce severe mental stress and anxiety [8].

The floods that hit the Bojonegoro area at the end of 2016 caused the losses for the people, such as the destruction of public property, public facilities and obstructed the access of cars and motorcycles, as well as inundated the paddy fields of the farmers. The loss of property and loss of families are also the effects of floods. Flood is the overflow of the river due to the water exceeds the capacity of the river shelter so that it overflows and inundates the surrounding plains or lower regions [9]. The perception that people gains from knowledge, will influence their behavior in the alertness efforts because the knowledge of disaster held an important role in the rescue process when a disaster occurs. The better understanding about the disaster will be to carry out appropriate rescue measures [10].

Disaster alertness in this study focuses on community emergency response plans for the flood disaster. Disaster emergency response plan is a collection of citizen agreement that will be executed in order to achieve something desired or expected. In this case is expected to improve the safety of floods, so as to reduce the occurrence of casualties or loss of property in 
case of flooding [11]. The emergency response plan is a crucial effort before the aid comes, and it is an important part of the alertness, especially in the relation of evacuation, help, and rescue so that disaster victims can be minimized [12]. The emergency response plan is a series of action plans that will be undertaken immediately during the disaster event to deal with adverse impacts, which include the rescue and evacuation of victims, property, basic needs, protection, refugee management, rescue and recovery of infrastructure and facilities [13]. Having an emergency disaster response plan for households and disasterrelated government agencies that is one of the two main stakeholders that expected to reduce disaster victims and reduce losses due to loss of property and destruction of essential facilities.

One of the areas affected by floods at the end of 2016 is Ledok Wetan village, Bojonegoro district, Bojonegoro regency. This are is frequently flooded, this is because the location is very concave or lower than Bengawan Solo River. Every time heavy rain there are always flood, it getting worse when more water from upstream river Bengawan Solo. The area is always submerge with varying depth, make villager's belonging and property washed away by the flood. The Floods strike every year, especially in the rainy season arrives. The villagers have recently experienced a period of oneyear long flood that might increase their knowledge about the flood disaster obtained from experience. This makes it possible that the villagers perception of the flood disaster itself is getting better. Based on the above backgrounds, this research aims to examine how the influence of people's perception on the flood disaster plan response emergency in Ledok Wetan, Bojonegoro, Bojonegoro district in East Java Province.

\section{Material and methods}

\subsection{Study area}

This research was conducted in February - April 2017, the research site is located in Ledok Wetan Village, Bojonegoro, Bojonegoro District. Because this area is often inundated by flooding as shown in Fig. 1

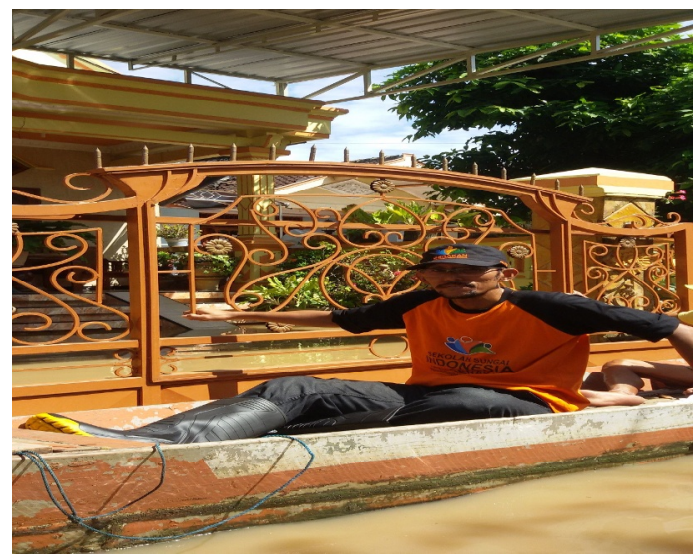

Fig. 1 The village head is oberving the flood

\subsection{Research methods}

The research method used is a quantitative method with a survey approach. Population in this research is all head of the family (Kepala Keluarga, KK) in Ledok Wetan Village, Bojonegoro Sub-district, Bojonegoro Regency, East Java Province. The village consist of 350 head of the family (KK). Sampling method is conducted by using the chart of the Harry King Nomogram [14] that stated that if the population is 350 with a $90 \%$ confidence level or error rate of $10 \%$. The sampling method used is Simple Random Sampling method, where it is a sampling from a random population without considering strata in the population [14]. Therefore, the sample size of this research is 46 head of the family who live in Ledok Wetan village. The data collected in this research are primary data and secondary data:

1. Primary data in this study obtained from the results of the questionnaire, the results of field surveys and documentation.

2. Secondary data in this study were obtained from record data of Ledok Wetan village, Bojonegoro district, Bojonegoro Regency.

\subsection{Data analysis technique}

Data analysis technique in this research is quantitative analysis, by using the Statistical Product and Solution Program (SPSS) version 16.0. Data analysis technique used is the Pearson Product Moment (PPM) technique, with the following steps.

\subsubsection{Test data normality}

Normality test is run to identify the normality of research data distribution. Although the population data is always normally distributed because the population always has a normal distribution [15]. In this research, the data of the normality test is based on Kolmogorov-Smirnov and Shapiro Wilk test and the tools used to calculate is SPSS Version 16.0. If the value of Sig $>\alpha(0.05)$, then the data is normally distributed. If the value of $\mathrm{Sig}<\alpha(0.05)$, then the data is not normally distributed

\subsubsection{Linearity test}

Tests on SPSS by using Test For Linearity with a significance level of error $(\alpha)$ of $5 \%$ or 0.05 . Two variables are said to have a linear relationship when the significance (linearity) is less than 0.05. [16].

By using software SPSS version 16.0. the provisions are:

a. If $\mathrm{F}$ arithmetic $<\operatorname{Sig} \alpha(0,05)$, then data is linear

b. If Fcount $>$ Sig $\alpha(0,05)$, then data is not linear

\subsubsection{Homogeneity test}

Homogeneity test aims to find out whether from several groups of research data has the same variance or not. By using SPSS software version 16.0 the provisions are: a. If Sig $>\alpha$, then the data is homogeny 
b. If $\operatorname{Sig}<\alpha$, then the data is not homogeneous

\subsubsection{Pearson product moment test (PPM)}

Pearson Product Moment Test is used to find the degree of relationship or influence and the contribution of independent variables (independent) with dependent variable (dependent). The correlation of PPM is denoted (r) with the provision that the value of $\mathrm{r}$ is not more than the price $(-1<\mathrm{r}<+1)$. Suppose the value of $\mathrm{r}=-1$ means the correlation is perfectly negative, $r=0$ means no correlation and $\mathrm{r}=1$ means the correlation is very strong. While the meaning of price $r$ will be consulted with the interpretation table $r$ value according to Guilford [14] is as follows:

Table 1. Interpretation of correlation coefficient of $r$ value

\begin{tabular}{|c|c|}
\hline Coeficient Interval & Relationship Level \\
\hline $0.00-0.199$ & Very low \\
\hline $0.20-0.399$ & Low \\
\hline $0.40-0.599$ & Medium \\
\hline $0.60-0.799$ & Strong \\
\hline $0.80-1.000$ & Very strong \\
\hline
\end{tabular}

Furthermore, to state the size of the contribution of variable $\mathrm{X}$ to $\mathrm{Y}$ can be determined by determinant coefficient formula as follows:

Information:

$$
K D=r^{2} \times 100 \%
$$

$\mathrm{KD}=$ Determinant Coefficient Value $\mathrm{r}=$ Correlation Coefficient Value

\subsection{Research instrument}

Instrument variable $\mathrm{X}$ in this research is the public perception of flood disaster and variable $\mathrm{Y}$ is the flood disaster emergency response plan. The instrument used in this research is the questionnaire. The acknowledgment of the public perception about flood disaster has used the choice yes - no answer. Score 2 is allocated for the answer yes, and score 1 for no answer, with 16 questions. To obtain data on the flood disaster plan response emergency, yes - no answer option is used. Score 2 for the answer yes, and score 1 for no answer, with 16 questions.

\subsection{Instrument trial}

\subsubsection{Test instrument validity}

In this study, the questionnaire instrument was tested for validity using the validity of the question items through statistical calculations using SPSS version 16.0. Testing is done by Product Moment analysis from Pearson, with a $5 \%$ error level [14], by comparing the significance level with error rate $\alpha$ (alpha) $=0.05$. Provided if the level of significance count is smaller than the error rate $\alpha$ (alpha), or Sig $\leq 0.05$ then the item is considered invalid, while if the level of significance count is greater than the error rate $\alpha$ (alpha) 0.05 or $\mathrm{Sig} \geq 0,05$ then item is considered valid.

\subsubsection{Test reliability instruments}

Instruments that are reliability are instruments that, when used multiple times to measure the same object, will produce the same data [14]. The valid question items are then tested for reliability by using Cronbach Alpha technique, Calculation of instrument reliability in this study using SPSS 16.0.

\section{Results and discussion}

\subsection{Community perception about flood disaster (variable $\mathrm{X}$ )}

Based on the results of research obtained from the field, then obtained a picture of public perception about flood disaster respondents as follows:

Table 2. Distribution of community perception score on flood of respondents

\begin{tabular}{|c|c|c|c|c|}
\hline Category & Formula & $\begin{array}{l}\text { Score } \\
\text { range }\end{array}$ & $\begin{array}{l}\text { Respondent } \\
\text { Frequency }\end{array}$ & Percentage \\
\hline High & $\begin{array}{l}\mathrm{X}>\mathrm{M}+\mathrm{S} \\
\mathrm{D}\end{array}$ & $\begin{array}{l}>31,3 \\
3\end{array}$ & 5 & $11 \%$ \\
\hline Medium & $\begin{array}{l}\mathrm{M}- \\
\mathrm{SD} \leq \mathrm{X} \leq \\
\mathrm{M}+\mathrm{SD}\end{array}$ & $\begin{array}{l}26,26- \\
31,33\end{array}$ & 34 & $74 \%$ \\
\hline Low & $\begin{array}{l}\mathrm{X}<\mathrm{M}- \\
\mathrm{SD}\end{array}$ & $\begin{array}{l}<26,2 \\
6\end{array}$ & 7 & $15 \%$ \\
\hline \multicolumn{3}{|l|}{ Amount } & 46 & $100 \%$ \\
\hline
\end{tabular}

Source: Research results April 2017

From the results of research conducted in Ledok Wetan Village, Bojonegoro District, it was found that public perception about flood disaster was in the medium category with $74 \%$. This indicate that the community is knowledgeable about the flood disaster. Furthermore, respondents who have the high category perceptions as much as $11 \%$ and $15 \%$ of respondents who have low perception. Public perceptions are derived from their beliefs, learning process, horizons, experiences, and knowledge of their own environment. Based on the results of the research, the more dominant influence perception is their knowledge and experience due to repeated flood disasters. This is because the majority of respondents are more than 20 years old and their origin are from the villager, so their knowledge of the flood disaster is derived from their past experiences.

\subsection{Emergency response plan (Variable $\mathrm{Y}$ )}

Based on the results of the research, emergency response plans for the community are described as in following table 3. 
Table 3. Distribution of respondent response emergency

\begin{tabular}{|c|c|c|c|c|}
\hline $\begin{array}{c}\text { Catego } \\
\text { ry }\end{array}$ & Formula & $\begin{array}{l}\text { Score } \\
\text { Range }\end{array}$ & $\begin{array}{l}\text { Respondent } \\
\text { Frequency }\end{array}$ & $\begin{array}{c}\text { Percen } \\
\text { tage }\end{array}$ \\
\hline High & $\mathrm{X}>\mathrm{M}+\mathrm{SD}$ & $>31,33$ & 7 & $15 \%$ \\
\hline $\begin{array}{l}\text { Mediu } \\
\mathrm{m}\end{array}$ & $\begin{array}{c}\mathrm{M}- \\
\mathrm{SD} \leq \mathrm{X} \leq \mathrm{M}+ \\
\mathrm{SD}\end{array}$ & $\begin{array}{c}26,26- \\
31,33\end{array}$ & 36 & $78 \%$ \\
\hline Low & $\mathrm{X}<\mathrm{M}-\mathrm{SD}$ & $<26,26$ & 3 & $17 \%$ \\
\hline \multicolumn{3}{|c|}{ Amount } & 46 & $100 \%$ \\
\hline
\end{tabular}

Source: Research results April 2017

Research results show that the emergency response plan of a flood in the high category with the percentage is calculated at $15 \%$. Furthermore, the medium category with the percentage of $78 \%$ and then the low category of $7 \%$. This means that the community is sufficiently able to prepare an emergency response plan in case of a flood disaster.

\subsection{Test data validity}

Prior to the research, the questionnaire items were tested on the validity. The validity of 46 respondents with the number of questions for each variable are 16 items. From the results of the calculation is known that a valid question for the $\mathrm{X}$ variable as many as 16 questions. The item is valid if the result of calculation with Pearson Product Moment Correlation is bigger than $r$ tabel $(0,290)$. Of the 16 items, a valid question for the $Y$ variable is 16 statements. The statement item is valid if the result of calculation with Pearson Product Moment Correlation is bigger than $r$ tabel $(0,290)$.

\subsection{Test reliability}

After the questionnaire item is tested for the validity of the data, then the item is tested for the reliability based on Cronbach's Alpha. From the calculation obtained reliability results variable $\mathrm{X}$ is equal to 0,643 . This matched the results with the Guilford reliability rule table that the data belongs to the category of reliability that is with sufficient reliability coefficient between 0.4 to 0.7 . For variable $\mathrm{Y}$ is equal to 0,708 . This results matched the results with the Guilford reliability rule table and the data is included in the category of reliability that is with the Reliability Coefficient 0.7-0.9.

\subsection{Normality test}

The normality test is performed to determine whether the distribution of a data obtained follows or approximates the normal distribution law of the default Gauss. The normal distribution of data when drawn with a polygon graph will resemble a bell, bell or bell. Data can be stated normally if $\operatorname{sig}(\alpha)>0,05$ and data is not normal if $\operatorname{sig}(\alpha)<0,05$. In the normality test table using the Kolmogorov-Smirnov One-Sample Test menu. Normality significance value on variable (X) is $0.092>$ 0,05 then this variable has normal data distribution, and for normality significance value at variable (Y) $0,058>$ 0,05 then this variable also has normal data distribution.

\subsection{Linearity test}

To observe whether the two variables have a good regression or not then the linearity test has conducted. This test is usually used as a requirement in correlation analysis or linear regression. Linearity test in this study using ANOVA can be seen significantly from linearity, if the sign is $<0,05$ can be concluded that the relationship is linear. Based on the calculation using SPSS version 16.0 , it is known that in the ANOVA table shows the significance count with $\operatorname{sig}(\alpha) 0.05$ is 0.000 . The calculated significance number $(0,000)<\alpha(0.05)$, so H0 is accepted which means that linear or linear data are met. The use of the ANOVA table is to facilitate the analysis of several groups of samples located with the smallest risk of error, and to know the significance of the average difference between the sample groups with each other. With the results of this linearity test, the research data has been qualified for PPM test to test its influence.

\subsection{Homogeneity test}

Homogeneity test aims to find out whether from several groups of research data has the same variance or not. The hypotheses tested were:

$\mathrm{H} 0=$ Variance of each group is the same (homogeneous) $\mathrm{H} 1$ = Variance of each group is not same (not homogeny)

By using SPSS software version 16.0 the provisions are: a. If $\mathrm{Sig}>\alpha(0.05)$, then the data homogeneous b. If Sig $<\alpha(0.05)$, then the data is not homogeneous

Based on the output in the table of the test of homogeneity using SPSS 16.0 note that the significance level count 0.641 . Figures $0.641>0.05$ then $\mathrm{H} 0$ accepted means that the variance of each group is the same.

\subsection{Pearson product moment (PPM)}

Hypothesis testing in this research using Pearson Product Moment with independent variables of public perception about flood disaster $(\mathrm{X})$ and as the dependent variable is flood disaster response plan (Y). The following table 4 presents the PPM analysis.

Table 4. Pearson product moment test results

\begin{tabular}{|c|c|c|c|}
\hline & & $\begin{array}{c}\text { Total } \\
\text { Partici } \\
\text { pation }\end{array}$ & $\begin{array}{c}\text { Total } \\
\text { Emergency } \\
\text { Response Plan }\end{array}$ \\
\hline \multirow{3}{*}{$\begin{array}{c}\text { Total } \\
\text { Participati } \\
\text { on }\end{array}$} & Pearson Correlation & 1 & $933^{* *}$ \\
\hline & Sig. (2-tailed) & & .000 \\
\hline & $\mathrm{N}$ & 46 & 46 \\
\hline \multirow{3}{*}{$\begin{array}{c}\text { Total } \\
\text { Emergenc } \\
\text { y } \\
\text { Response } \\
\text { Plan }\end{array}$} & Pearson Correlation & $933^{* *}$ & 1 \\
\hline & Sig. (2-tailed) & .000 & \\
\hline & $\mathrm{N}$ & 46 & 46 \\
\hline
\end{tabular}


At the above correlation output, it can be seen that the significance level of the count is 0,000 while the specified error rate $(\alpha)$ is 0.05 . Thus, the count significance level $(0,000)$ <error rate $(0.05)$. In this research, the research hypothesis tested are:

$\mathrm{H} 0=$ There is no influence between the public perception of flood disaster on the flood disaster emergency response plan

$\mathrm{H} 1=$ There is an influence between the public perception of flood disaster on the flood disaster emergency response plan.

Based on the output calculation on the PPM table obtained a correlation rate between the public perception of the flood disaster on the plan's response emergency of 0.933. Based on the Guilford correlation table, the numbers fall into very strong categories because they are in the range of $0.80-1,000$. For the direction of influence, because the value of $r$ is positive means the higher the public perception of the flood disaster then increase the emergency response plan flood disaster. The level of significance count $(0,000)<$ error rate $(0.05)$ then $\mathrm{H} 0$ is rejected, meaning that there is an influence between the public perception of the flood disaster on the plan of emergency response of flood disaster.

\subsection{Coefficient of determination}

To identify the effect of variable $\mathrm{X}$ to $\mathrm{Y}$, then used the formula coefficient of determination as follows:

$$
\begin{aligned}
\mathrm{KD} & =\mathrm{r}^{2} \times 100 \% \\
& =(0,933)^{2} \times 100 \% \\
& =87 \times 100 \%=87 \%
\end{aligned}
$$

Based on the calculation of determination coefficient obtained value $87 \%$. This shows that the percentage of contribution of independent variables (public perception about flood disaster) to dependent variable (Flood disaster emergency response plan) is $87 \%$.

\section{Conclusions}

Based on the results of the study, it can be concluded that there is an influence between the public perception of the flood disaster on the plan of emergency response of flood disaster. From the results of Pearson Product Moment analysis, obtained value (r) is 0.933 in Guilford correlation rules, the number is in the range 0.80 to 1.000 which means it is having a very strong level of relationship or influence. It is also supported by BPBD (local disaster management agency) public relations explanation that the current flood is no longer a problem but a blessing for Bojonegoro.

Some residents and village heads of Ledok Wetan are familiar with the flood and they consider it is not a problem.

Based on the determinant coefficient $(\mathrm{R})$, the figure is $87 \%$. Research results show that theoretically the public perception of the flood affected the disaster emergency response plan of flood disaster; but in the reality is not fully applicable. This is because there are other factors that affect $13 \%$ apart from the public perception in determining the emergency of plan response for flood disaster that is not described in this study.

\section{References}

1. Department of Communication and Information of the Republic of Indonesia. 2008. Understanding Disasters. Jakarta: Department of Communication and Information of the Republic of Indonesia

2. Robert J. Kodoatie, Sugiyanto. 2002. Flooding Several Causes and Control Methods in an Environmental Perspective. Yogyakarta: Pustaka Pelajar.

3. Schwab, G, O., Fangmeier, D, D., Elliot, W,J,E., Frevert, R,K., 1997. Soil and Water Conservation Techniques (Book 1 of 2). Center For Land and Water Management Studies. Sriwijaya University.

4. Noson, L. (2000). Hazard Mapping and Risk Assesment, Proceeding of The Regional Workshop on Best in Disaster Mitigation.

5. Mistra. 2007. Anticipation of Houses in Flood Prone Areas, Griya Kreasi. Jakarta

6. Zoleta-Nantes, D. B. (2000). Flood Hazard Vulnerabilities and coping strategies of residents of urban poor settlements in Metro Manila, the Philippines. In D. J. Paker (Ed)., Floods (pp.69e88). London: Routledge.

7. Blaikie, P., Cannon, T., Davis, I., \& Wisner, B. (2003). At risk: Natural hazards, People's vulnerability, and disasters. New York: Routledge.

8. Green, C.H., Tunstall, S. M, \& Fordham, The Risk from flooding: which risks and whose perceptions? Disasters, 15 (3),22e236.

9. Yulaewati, Ella. 2008. Intelligent with Grasindo). Jakarta

10. Wicaksono, willy, 2007. Guidelines for Facing Earthquake and Tsunami Disasters. Ikreasi, Jakarta

11. Rahayu, P.Harkunti, dkk. 2009. Flooding and its Management. PROMISE Indonesia. Bandung.

12. LIPI-UNESCO/ISDR. 2006. Study of Preparedness in Aticipating Earthquake and Tsunami Disasters. Deputy of Earth Sciences, Indonesia Institute of Science. Jakarta.

13. Ramli, Soehatman. 2010. Practical Guidelines for Disaster Management. Dian Rakyat. Jakarta

14. Sugiyono. 2009. Statistics for Research. Alfabetta. Bandung.

15. Purwanto.2008. Qualitative Research Methodology for Psychology and Education. Pustaka Pelajar. Yogyakarta.

16. Priyatno,Dwi. 2008. Learning SPSS for Data Analysis and Statistical Test. Mediakom. Yogyakarta.

17. Kundzewics, Zbigniew W., Shinjiro K., Sonia I., John H., Neville N., Pascal P., Reinhard M., Laurens 
M., Nigel A., Katharine M., Robert M., G. Robert, Wolfgang K., Gerardo B., Yasushi H., Kiyoshi T., \& Boris S. 2012. Flood Risk and Climate Change:

Global and Regional Perspectives. London: Hydrological Sciences Journal. Vol. 59, No. 01: 128 